JOSAR, Vol. 2 No. 1 March, 2017; p-ISSN: 2502-8251; e-ISSN: 2503-1155

Copyrights@ Balitar Islamic University, Blitar-Indonesia

http:josar.unisbablitar.ejournal.web.id

\title{
ROOT AND STEM IN ENGLISH AND ARABIC LANGUAGE
}

\author{
Rika Lestari ${ }^{\star 1}$, Retno Fitriani ${ }^{\star 2}$, Dinda Nurlaili³ ${ }^{\star 3}$ Lutfi Nuraini Ismaiyah ${ }^{\star 4}$, Kevin \\ Fawaizul Umam*5, Bayu Bimantara ${ }^{\star 6}$ \\ 1,2Islamic University of Balitar; Jl. Majapahit No. 04, Telp. (0342)813145 \\ ${ }^{3}$ Program Studi Pendidikan Bahasa Inggris , FKIP Universitas Islam Balitar, Blitar \\ e-mail: ${ }^{* 1}$ rhikalesthari@gmail.com, ${ }^{2}$ retnofitriani123@gmail.com, \\ 301indanurlaili99@gmail.com, ${ }^{4}$ lutfinuraini2204@gmail.com, ${ }^{5}$ kfawaizulumam@yahoo.com, \\ 6bimantarabayu06@gmail.com
}

\begin{abstract}
The root and stem are the lowest levels at which a language speificific structure can be categorized. Additional categorization is the syntac level. An empirical study comparing root and stem categorization in a sample of two languages (English and Arabic) shows far-reaching distinctions. Therefore the researchers conducted the research about root and stem in arabic and english. The research method that was used is descriptive qualitative method. To gain the data the researchers used literature review in which the data gained from dictionary, English and arabic articles. The data analysed by using content analysis. These variations in the categorization of linguistic signs at the most fundamental levels cast doubt on any thesis claiming universal categorization or stem categorization. Such a static perspective should be substituted by a vibrant perspective demanding the role of categorization in linguistic operation.
\end{abstract}

Keywords: linguistic,english, arabic, root and stem, categorize

\section{INTRODUCTION}

Morphology is the study of words, how they are formed, and how structures in other words in language. It analyzes the structure of words and part of words. Morphology also looks at part of speech, intonation and stress and context of words meaning.

The two branches of morphology are the study of breaking apart (the analytical side) and the reassembly (the synthetic side) of words; wit, inflectional morphology is about breaking apart words into their components, such as how suffixes produce distinct types of verb. Lexical word formation, on the other hand, relates to the building of new basic words, particularly complicated ones. Lexical word formation is also called lexical morphology and derivational morphology. 
JOSAR, Vol. 2 No. 1 March, 2017; p-ISSN: 2502-8251; e-ISSN: 2503-1155

Copyrights@ Balitar Islamic University, Blitar-Indonesia

http:josar.unisbablitar.ejournal.web.id

A morpheme is not same as a phrase, and the main distinction between the two is that a morpheme may or may not be standing alone, while a phrase is standing alone by definition. Morphology is the linguistic field of research devoted to morphemes. When a morpheme stands alone, it is regarded a root because it has its own significance and depends on a root. In this paper, we are going to talk about root and stem.

A root is the core of a word. A root can be free or bound. Root can be free morpheme or a word element which the other new words grow, usually through addition prefixes and suffixes.

Example: unhappy, root: happy.

Stem is a word element to which grammatical or inflectional suffixes can be added. Every word that end with inflectional suffixes, we called it 'stem'. A stem consists minimally of a root, but may be analyzable into a root plus derivational morphemes. A stem may require an inflectional operation (often involving a prefix or suffix) in order to ground it into discourse and make it a fully understandable word. If a stem does not occur by itself in a meaningful way in a language, it is referred to as a bound morpheme.

'Root' and 'stem' are all terms used in the literature to designate that part of a word that remains when all affixes have been removed.

A root is a form which is not further analysable, either in terms of derivational or inflectional morphology. It is that part of word-form that remains when all inflectopional and derivational affixes have been removed.

A root is the basic part always present in a lexeme. In the form 'untouchables' the root is 'touch', to which first the suffix '-able', then the prefix 'un' and finally the suffix '-s' have been added. In a compound word like 'wheelchair' there are two roots, 'wheel' and 'chair'.

A stem is of concern only when dealing with inflectional morphology.

In the form 'untouchables' the stem is 'untouchable', although in the form 'touched' the stem is 'touch'; in the form 'wheelchairs' the stem is 'wheelchair', even though 
JOSAR, Vol. 2 No. 1 March, 2017; p-ISSN: 2502-8251; e-ISSN: 2503-1155

Copyrights@ Balitar Islamic University, Blitar-Indonesia

http:josar.unisbablitar.ejournal.web.id

the stem contains two roots. ( Taken from: Bauer, Laurie (1983:20-21): English

word-formation. Cambridge: Cambridge University Press)

Examples:

- The verbs tie and untie are both stems.

- The inflectional third person singular suffix -s may be added to the stems to form ties and unties.

Morphologically complex words consist of a morpheme root and one or more affixes. Some examples of English roots are paint in painter, read in reread, and ling in linguist. Root can stand alone or not as a word [paint, read;can stand alone], [ling ; cannot stand alone].

If the root combined with affix, it form a stem. Other affixes can be combine with root to be complex stem is:

$\begin{array}{llll}\text { Root } & \text { system } & & \\ \text { Stem } & \text { system } & + & \text { noun } \\ & \text { atic } & \text { noun }+ \text { suffix }\end{array}$

\section{RESEARCH METHOD}

Research method is a science way of obtaining information with particular purposes and uses, according to Prof. Dr. Sugiyono. Research methods can be grouped into several types. The various research methods are as follows: qualitative methods, quantitative methods, survey methods, facto exposures methods, and descriptive methods.

Because of this research use describes an event that is ongoing in the present and also in the past, and this research produces descriptive data consisting of written or oral words from people and observed research, the researcher uses qualitative descriptive as a research method.

The data gained by using literature review. The researcher searched the data by using dictionary and english and arabic articles. Then, those data analysed by using content analysis. 
JOSAR, Vol. 2 No. 1 March, 2017; p-ISSN: 2502-8251; e-ISSN: 2503-1155

Copyrights@ Balitar Islamic University, Blitar-Indonesia

http:josar.unisbablitar.ejournal.web.id

\section{RESULT AND DISCUSSION}

\section{A. Word}

Word is a speech sound or a combination of sounds, or its written representation, which symbolizes and communicates a meaning and may consist of a single morpheme or a mixture of morphemes.

According to Kridalaksana (2008: 110) words have the understanding 1) morpheme or combination of morphemes which by the language is considered as a unit the smallest that can be spoken as a free form, (2) units of language that may be stand-alone composed of a single morpheme or a mixture of morphemes; (3) the lowest units of syntax derived from lexemes that have undergone a morphological process.

Therefore, from the above notions we can conclude that word is a language element consisting of a collection of units or letters that have meaning and function to form a sentence, phrase and clause.

\section{Type of words}

a. Noun

A noun is an individual, location, object, quality, or act.

Examples: shoes, tortoise, rage, sorrow, city

b. Verb

Verbs are words of action or presence telling what nouns are doing.

Examples: laugh, read, watch

c. Adjective

An adjective is described a noun

Examples: Heavy, helpful, bald

d. Adverb

An adverb refers to a verb, adjective, or adverb. In ' ly ' it often finishes.

Examples: patiently, merely.

e. Interjection

Interjection is an outcry or a sudden utterance. Usually a phrase begins.

Examples: God, ouch, my 
JOSAR, Vol. 2 No. 1 March, 2017; p-ISSN: 2502-8251; e-ISSN: 2503-1155

Copyrights@ Balitar Islamic University, Blitar-Indonesia

http:josar.unisbablitar.ejournal.web.id

f. Preposition

A preposition describes the relationship between a noun and another noun (or verb or adverb).

Examples: down, at, from, to

g. Conjunction

A conjunction joins together words, phrases, or clauses.

Examples: but, and, so

h. Pronoun

A pronoun replaces a noun or noun phrase that is understood from context.

Examples: she, me, it

The example of word:

"The man looked at the horses"

In the sentence above " $\mathrm{s}$ " is the plural marker, dependent on the noun horse to receive meaning. Horse is a word can occur in other positions or stand on its own.

\section{B. Morpheme}

\section{Free Morpheme}

Free morpheme is the root that can stand alone.

Examples: walk, stand, happy, style, create, clever, sing.

Free morpheme is divided into two:

\section{a. Lexical Morpheme}

Lexical morpheme is morpheme containing the content or meaning of the messages we convey.

Examples: Act, pick, yellow, strange, follow, type, look. 
JOSAR, Vol. 2 No. 1 March, 2017; p-ISSN: 2502-8251; e-ISSN: 2503-1155

Copyrights@ Balitar Islamic University, Blitar-Indonesia

http:josar.unisbablitar.ejournal.web.id

\section{b. Functional Morpheme}

Functional Morpheme is morphemes that do not perform a message's content, but instead assist the sentence function's grammar.

Examples: Above, in, if, but, when, near, the, that, them.

\section{Bound Morpheme}

Bound morpheme is the root that cannot stand alone.

\section{Example:}

\section{Hamlet by William Shakespeare}

"Sit down awhile;

And let us once again assail your ears, That are so fortified against our story

What we have two nights seen.

Before my God, I might not this believe without the sensible and true avouch of mine own eyes."

All the underlined words in this example are bound morphemes, as they cannot exist independently. For instance, "awhile" is a combination of two morphemes "a" and "while."

Bound morpheme is divided into two:

\section{a. Inflectional Morpheme}

Inflectional morpheme is morpheme showing aspects of a word's grammatical function, such as transforming a word into a plural or possessive form.

Examples: -er, -est, -ed, -en, -ing.

1) Small= Adjective

$$
\text { Small }+ \text { er } \quad=\text { Adjective }
$$
2) Long
$=$ Adjective 
JOSAR, Vol. 2 No. 1 March, 2017; p-ISSN: 2502-8251; e-ISSN: 2503-1155

Copyrights@ Balitar Islamic University, Blitar-Indonesia

http:josar.unisbablitar.ejournal.web.id

$$
\text { Long }+ \text { est } \quad=\text { Adjective }
$$

3) Walk = Verb

Walk + ed $=$ Verb

4) Give = Verb

Give + en $=$ Verb

5) Write = Verb

Write + ing $=$ Verb

b. Derivational Morpheme

Derivational morpheme is morpheme that convert phrases from the root word (a free morpheme) into distinct grammatical categories.

Examples: -y, -ish, -ment, -ness, -less, -ful, -ly.

1) Health = Noun

Health $+y=$ Adjective

2) Fool= Noun

Fool + ish $=$ Adjective

3) Agree = Verb

Agree + ment $=$ Noun

4) Kind = adjective

Kind + ness = noun

5) Home = Noun

Home + less = Adjective 
JOSAR, Vol. 2 No. 1 March, 2017; p-ISSN: 2502-8251; e-ISSN: 2503-1155

Copyrights@ Balitar Islamic University, Blitar-Indonesia

http:josar.unisbablitar.ejournal.web.id

6) Care = Noun

Care + ful $\quad=$ Adjective

7) Weak = Adjective

Weak $+l y=$ Adverb

\section{Root And Stem}

Root is a form that cannot be further analyzed, either in terms of morphology derivative or inflective.

Only when it comes to inflectional morphology is a stem.

\section{Examples:}

1) Paint + er $=$ Painter

Root + Stem $=$ Word

Painter is a kind of word. It contains from stem and root. In conclusion, we can say that stem + root $=$ word. In the other word, we say painter.

2) $\mathrm{Re}+\mathrm{read}=$ Reread

Stem + Root $=$ Word

Reread is a kind of word. It contains from stem and root. In conclusion, we can say that stem + root = word. In the other word, we say reread.

3) Con + ceive $=$ Conceive

Stem + Root $=$ Word

Conceive is a kind of word. It contains from stem and root. In conclusion, we can say that stem + root = word. In the other word, we say conceive. 
JOSAR, Vol. 2 No. 1 March, 2017; p-ISSN: 2502-8251; e-ISSN: 2503-1155

Copyrights@ Balitar Islamic University, Blitar-Indonesia

http:josar.unisbablitar.ejournal.web.id

4) Ling + uist $=$ Linguist.

Root + Stem $=$ Word

Linguist is a kind of word. It contains from stem and root. In conclusion, we can say that stem + root $=$ word. In the other word, we say linguist.

Another example of root and stem for write in Egyptian Arabic is كَتَكَfrom which following word (among others) are formed by infixing vowels:

a. كآتبِب

Kaatib 'writer' $=$ word

Root

Stem $=1$

كآتِب كآتِب

b. كِنَابٌ

Kitaab 'book' = word

Root $=$

Stem $=1$

كِنَابُ is a kind of word. It contains from stem and root. In conclusion, كِكَّبُ

C.

Yadribu 'will hit or hitting' =word

= root

= stem

is a kind of word. It contains from stem and root. In conclusion, we can say that stem + root = word. In the other word, we say يَضْرِبُ 
d. أْنْصُْْ

Unshur 'please help' = word

نَصَرَ root

I and $\dot{\circ}=$ stem

is a kind of word. It contains from stem and root. In conclusion, أُنْصُرْ

Another example in Arabian Language:

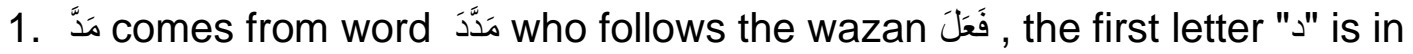
sukun (ْ) because it the terms is idolized, so be the word then the letter "د "د "د " because the letters are the same the word

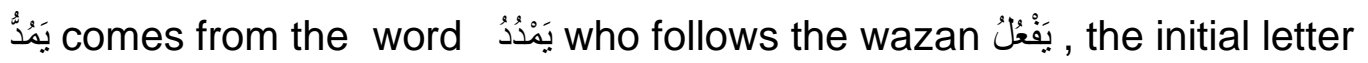
"د" is moved to the letter before "د" because the term is idolized, then be the word يَمْدُدُ , then the letter "د" is added to the second because the letter are same so the word يَُّ is formed

مَنَ

"ي" in Arabian language is potitioned as stem because it functions as a prefix. In Arabian language this is called "Fi'il Mudhori' " which means lenghthen

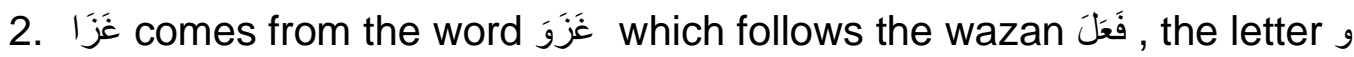
is replaced with the letter I because of the letter before $g$ is populated by fathah (َ) so difficult to pronounce, than be letter

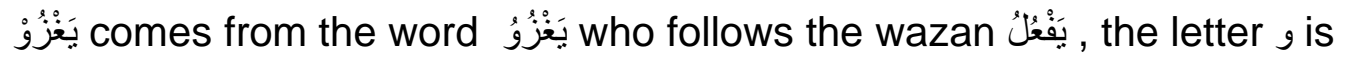
in sukun (ं) because of the weight of the letter $و$ which is populated by dhummah (َ) then be the word يَغْزُو . 
JOSAR, Vol. 2 No. 1 March, 2017; p-ISSN: 2502-8251; e-ISSN: 2503-1155

Copyrights@ Balitar Islamic University, Blitar-Indonesia

http:josar.unisbablitar.ejournal.web.id

يَغْزُوْ غَ become

In Arabian language is potitioned as stem because it functions as prefix. In Arabian Language this is called "Fi'il Mudhori' "which mean war.

3. صَسَونَ Comes from the which follows the wazan فَعَلَ , the letter $g$ is replaced with the letter I because of the letter before $g$ is populated by fathah (َ) so difficult to pronounce, than be letter صَانَ.

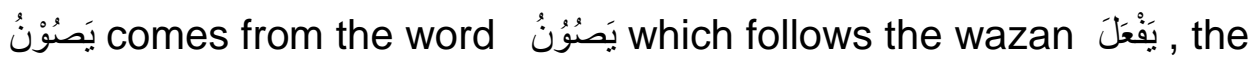
wakat of wawu (و) is moved to the previous letter because of the weakness of the letter (و) bearing the title of dhummah (s) and the strongness of the letter shahih bearing the title then be the word يَصُوْنُ .

نَصَصْونُ become

In Arabian language is potitioned as stem because it functions as prefix. In Arabian Language this is called "Fi'il Mudhori' "which mean guard.

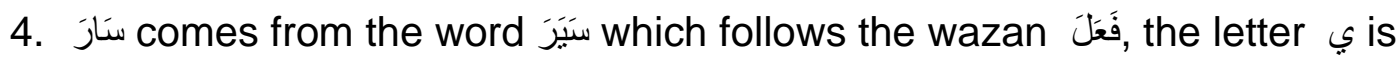
replaced with the letter alif (।) because of the letters before is populated by fathah (1) so difficult to pronounce, then be the word .

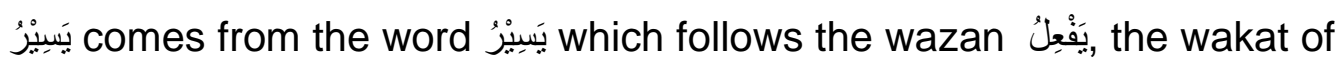
is moved to the previous latter because of the weakness of the letter bearing the title, and the strongness of the letter shahih bearing the title, then be the word يَسِيْرِ .

يَسِيْرِ 
JOSAR, Vol. 2 No. 1 March, 2017; p-ISSN: 2502-8251; e-ISSN: 2503-1155

Copyrights@ Balitar Islamic University, Blitar-Indonesia

http:josar.unisbablitar.ejournal.web.id

in Arabian Language is positioned as stem because it functions is as prefix. In Arabian Language this is called "Fi'il Mudhori' ". Which mean walk.

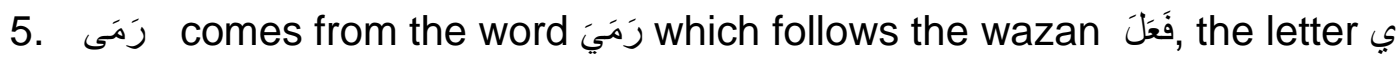
is replaced with the letter alif maksurah (l) .Because of the letter before is populated by fathah (1) so difficult to pronunce, then be the word

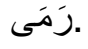

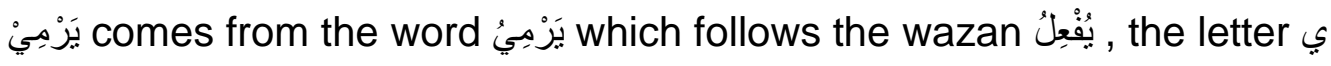

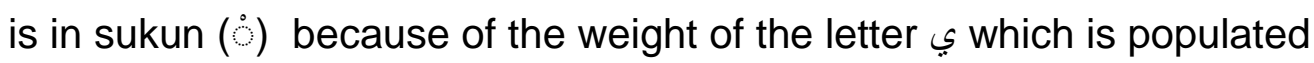
by dhummah (j) then be the word يَزْيَيْ .

يَرْمِيْ become رَمَى

in Arabian Language is potitioned as stem because it functions is as prefix. In Arabian Language this called "Fi'il Mudhori' " which mean throw.

\section{CONCLUSION}

Morphology is the structure of words. Morphology detail with the syntax of complex word and part of words, also called morpheme. Word is important part of linguistic knowledge. Morphemes are connected to existing lexical forms as affixes. Root can dependent or independent, root do not add with affix. Stem cannot dependent because the pattern is noun + suffix, noun is root or the basic and suffix is steam for added in a word. In Arabic the letters ي and I most be a stem in each word and change the meaning of word basically plus with $\dot{a}$ also as a stem like two letters it. But the name is Fi'il Modhori in Arabic is change another word or stem to another, like the letter it was changed or not and Fi'il Modhori can be categorized irregular verb in the English language, in order that same is the 
JOSAR, Vol. 2 No. 1 March, 2017; p-ISSN: 2502-8251; e-ISSN: 2503-1155

Copyrights@ Balitar Islamic University, Blitar-Indonesia

http:josar.unisbablitar.ejournal.web.id

case with the English language, the Arabic language also uses the rules of regular and irregular verb also.

\section{SUGGESTION}

For the result of this study can be used by other researchers as a comparison or reference in conducting literary research on Root and Stem material, such as genetic structuralism and literary receptions. More learning the linguistic categorize and do not use just one language for research to compare the result of different.

\section{Acknowledgment}

We as the researcher team would like to thank: God has given us grace so that researchers can complete this researcher,research parents who have helped prayer and all efforts in conducting research,Mrs. Miza Rahmatika A., SSa., MA as Lecturer in Morphology subject, friends who help carry out the research 
JOSAR, Vol. 2 No. 1 March, 2017; p-ISSN: 2502-8251; e-ISSN: 2503-1155

Copyrights@ Balitar Islamic University, Blitar-Indonesia

http:josar.unisbablitar.ejournal.web.id

\section{REFERENCES}

Caka, Nebi. 2014. Root, Stem, Base. Research Gate. 2 February.

Giordano, Andrea. 2015.Lexical, Functional, Derivational, and Inflectional Morphemes. Student Posts. 27 February.

Hamid, Abdul. 2016. Pengertian root, stem dan base. Motherfuckerz. 27 March.

Kerpan, John. 2015. What are some differences between stem, root and base (in the field of morphology)?Quora. 7 December.

Nordquist, Richard. 2019. What is the definition of word? ThoughtCo. 1 July.

Ossa, M.P. 2019. What are bases, roots and stems in English language? Please explain with examples.

Prasetyo, Agung. 2017. Free Morpheme and Bound Morpheme. Linguistik Id. 5 January.

Rahayu, Sri.2013. Definiton and Example of Morphology and Syntax. MyBloggerLab. 9 March. 